\title{
Soil fertility effects of repeated application of sewage sludge in two 30-year-old field experiments
}

\author{
Gunnar Börjesson (1D) Thomas Kätterer
}

Received: 13 June 2018/ Accepted: 17 September 2018/Published online: 24 September 2018

(C) The Author(s) 2018

\begin{abstract}
Recirculation of plant nutrients from waste materials back to agriculture is necessary in a sustainable food production system. In this study we investigated the long-term effect of direct land application of sewage sludge (SS) on soil fertility on two Swedish farms, where field experiments were set up in 1981 with three rates of SS (0, 4 and $12 \mathrm{Mg}$ dry matter ha ${ }^{-1}$ every 4 years) and three rates of mineral fertilisation, in a factorial design with four replicates. At one site, SS application tended to increase crop yield over time but, when plant nutrients were not limiting, the effect was only significant for spring barley. We deduced that improved soil structure was the main driver for this fertility enhancement after SS application, as indicated by lower soil bulk density and higher soil carbon concentration. After 30 years, soil organic carbon stocks to $0.40 \mathrm{~m}$ depth differed by up
\end{abstract}

Electronic supplementary material The online version of this article (https://doi.org/10.1007/s10705-018-9952-4) contains supplementary material, which is available to authorized users.

G. Börjesson ( $\square)$

Department of Soil and Environment, Swedish University of Agricultural Sciences, P.O. Box 7014, 75007 Uppsala, Sweden

e-mail: gunnar.borjesson@slu.se

\section{T. Kätterer}

Department of Ecology, Swedish University of Agricultural Sciences, P.O. Box 7044, 75007 Uppsala, Sweden to $17 \mathrm{Mg} \mathrm{ha}^{-1}$ between treatments. According to carbon balance calculations, retention of carbon derived from SS ranged between 18 and $20 \%$ for the soil layers analysed at the two sites. Soluble phosphorus $(\mathrm{P})$ increased with sludge application rate, but represented only around $2 \%$ of the expected residual $\mathrm{P}$ according to P-balance calculations. The fertiliser value of nitrogen was also low, with only $3-8 \%$ nitrogen use efficiency. Heavy metals such as copper, zinc and mercury showed moderate accumulation in the soil, but elevated levels of metals were not detected in crops, even at the highest dose of SS. These results show that SS represents a valuable resource for improving soil fertility in terms of soil organic matter and soil structure, but its efficiency for nutrient cycling is very low within the time frame considered in the study.

Keywords Sewage sludge $\cdot$ Soil $\cdot$ Carbon sequestration $\cdot$ Phosphorus

\section{Introduction}

Recycling the nutrients contained in food back to agriculture is essential for sustainability. Steadily increasing nutrient fluxes between urban and rural landscapes, driven by a growing human population, urbanisation and shifts in dietary preferences, are 
demanding sustainable recycling technologies, especially for sewage sludge (SS) from wastewater treatment plants, the major recycling pathway. In most countries, this involves use of SS as a fertiliser in agriculture (Eurostat 2015). In 2015, a total of 51,000 ton SS dry matter (DM) was used as fertiliser in Swedish agriculture (SWWA 2016), corresponding to $28 \%$ of all SS produced in Swedish wastewater plants in that year (STEM 2016).

Sewage sludge has several potential positive values, such as sequestration of carbon (Smith et al. 1997), addition of phosphorus (e.g. Andriamananjara et al. 2016) and improvement of soil structure (Kirchmann et al. 2017). However, the potential positive effects on soil fertility after direct land application of SS have to be weighed against the risk of soil contamination and against extraction technologies which aim at recycling nutrients in inorganic forms. Among potential negative effects of SS, heavy metal concentrations are still the greatest concern, although concentrations in SS have decreased, at least in Europe, due to source separation (López-Rayo et al. 2016) and lower airborne emissions from industries, and thus lower amounts in precipitation (Pacyna et al. 2009). Besides accumulation of heavy metals, different organic contaminants including microplastics are a concern and hinder direct land application of SS in many countries (e.g. Smith 2009a, b; Nizzetto et al. 2016).

European Union (EU) Directive 86/278/EEC, which sets limits for seven heavy metals, is currently being considered for revision (European Commission 2017). This is because many national authorities set lower limits for heavy metals than the EU directive, and also include organic contaminants (Inglezakis et al. 2014; Mininni et al. 2015; Mattsson et al. 2017). Swedish regulations also limit phosphorus (P) and nitrogen (N) application rates with SS (Suppl. Appendix 1; SNFS 1994). In addition, they provide recommendations on optimal application rates for $\mathrm{N}, \mathrm{P}$ and potassium $(\mathrm{K})$ depending on crop, location and time of application (Swedish Board of Agriculture 2016). A new fertiliser regulation is also proposed for the EU, which aims at creating common rules in Europe for all types of fertilisers, including organic fertilisers (European Commission 2016).

Field trials provide decision support for supervisory policies and regulations regarding the use of SS in agriculture. In order to provide robust information about impacts on soil fertility and food safety, field trials should be run for many years. Therefore two long-term field experiments with SS applied at normal and high rates were started in 1981 in southern Sweden. Reports in Swedish have been published continuously (e.g. Andersson 2015). Peer-reviewed articles based on data from these experiments describe the effects on microbial communities and heavy metals in crops (Börjesson et al. 2014), trace elements in cereal grain (Hamnér and Kirchmann 2015), metals in SS from wastewater treatment plants (Kirchmann et al. 2017) and the results of life cycle analysis (Heimersson et al. 2017). Investigations on organic contaminants have also been reported recently (Österås et al. 2015; Magnér et al. 2016).

The aim of the present study was to provide a broader picture of the trials, based on results obtained from regular analyses of crop yield and a more intensive soil sampling campaign conducted in 2011. The specific objective of the work was to test the following hypotheses:

1. Crop yield increases over time after repeated additions of sewage sludge.

2. Carbon sequestration is positively correlated with the amount of sewage sludge applied.

3. Sewage sludge supplies nutrients, especially $\mathrm{N}$ and $\mathrm{P}$, to crops.

4. If the recommended dose of sewage sludge is not exceeded, the plant availability of heavy metals in soil and their concentrations in harvested products will not increase significantly over time.

\section{Materials and methods}

\section{Site descriptions}

The trials with SS application on agricultural soils were laid down in 1981 at two sites in southern Sweden: Igelösa $\left(55^{\circ} 45^{\prime} \mathrm{N}, 13^{\circ} 18^{\prime} \mathrm{E}\right)$, on a loam $(26 \%$ clay, $44 \%$ sand $0.06-2 \mathrm{~mm})$, and Petersborg $\left(55^{\circ} 32^{\prime} \mathrm{N}\right.$, $\left.13^{\circ} 00^{\prime} \mathrm{E}\right)$, on a sandy loam ( $14 \%$ clay, $56 \%$ sand), both located on private farms. The trials have been managed by the Rural Economy and Agricultural Societies (Hushållningssällskapet) in Borgeby, Skåne, from the start. In the first year of the trials, soil carbon (C) concentration was $1.9 \%$ at Igelösa and $1.0 \%$ at Petersborg. The higher $\mathrm{C}$ levels at Igelösa are 
explained by a long time use as pasture before the experiment started.

Experimental design and management practices

The trials are laid out in a block design with four blocks, with all treatments included in each block (Table 1), but for practical reasons the treatments are made in columns and rows (Suppl. Fig. S1). The treatments include completely untreated control plots where no SS or mineral fertiliser has been added since 1981. Sewage sludge is applied every 4 years, after harvest, with 0,4 or $12 \mathrm{Mg} \mathrm{DM} \mathrm{ha}^{-1}$ per occasion (A, $\mathrm{B}, \mathrm{C}$ treatments, respectively). Plots with and without SS addition are combined with three different amounts of mineral fertiliser, no, half or full dose of $\mathrm{N}(0,1,2$ treatments, respectively) based on crop-specific fertilisation recommendations in the region (Table 1). The full dose is $140 \mathrm{~kg} \mathrm{~N}$ for wheat, $120 \mathrm{~kg} \mathrm{~N}$ for sugar beet and $110 \mathrm{~kg} \mathrm{~N}^{-1}$ for barley and oats. The recommended amounts of $\mathrm{P}$ and $\mathrm{K}$ are added at both half and full $\mathrm{N}$ input, with $17.5 \mathrm{~kg} \mathrm{P} \mathrm{ha}^{-1}$ for cereals and $42 \mathrm{~kg} \mathrm{P} \mathrm{ha}^{-1}$ for sugar beet. All treatments have four replicates, which means that there are three levels of $\mathrm{N} \times$ three levels of SS $\times$ four replicates $=36$ plots per site. Each plot measures $6 \mathrm{~m} \times 20 \mathrm{~m}$ and an area of around $20 \mathrm{~m}^{2}$ in the middle of each plot is normally used for yield measurements.

Anaerobically digested and dewatered SS from Sjölunda wastewater treatment plant in Malmö is applied to the experimental plots at Petersborg and SS from Källby treatment plant in Lund is applied at

Table 1 Yield 1981-2015 for all crops, normalised for the conventional treatment in region, where A2 = recommended dose of mineral nitrogen $(\mathrm{N})$ fertiliser without sewage sludge (SS)

\begin{tabular}{|c|c|c|}
\hline Treatments & Igelösa & Petersborg \\
\hline A0. No SS, no N & 55 & 48 \\
\hline A1. No SS, half N & 81 & 86 \\
\hline A2. No SS, full N & 100 & 100 \\
\hline B0. $1 \mathrm{Mg}$ DM SS ha ${ }^{-1} \mathrm{yr}^{-1}$, no $\mathrm{N}$ & 62 & 56 \\
\hline B1. $1 \mathrm{Mg}$ DM SS ha $\mathrm{yr}^{-1}$, half $\mathrm{N}$ & 88 & 90 \\
\hline B2. $1 \mathrm{Mg}$ DM SS ha ${ }^{-1} \mathrm{yr}^{-1}$, full $\mathrm{N}$ & 105 & 103 \\
\hline C0. $3 \mathrm{Mg}$ DM SS ha ${ }^{-1} \mathrm{yr}^{-1}$, no N & 72 & 64 \\
\hline C1. $3 \mathrm{Mg}$ DM SS ha $\mathrm{yr}^{-1}$, half $\mathrm{N}$ & 91 & 92 \\
\hline C2. $3 \mathrm{Mg}$ DM SS $\mathrm{ha}^{-1} \mathrm{yr}^{-1}$, full $\mathrm{N}$ & 105 & 106 \\
\hline
\end{tabular}

Igelösa, which is just north of Lund. Phosphorus in the wastewater is removed through precipitation with $\mathrm{FeCl}_{3}$. The quality of the SS is monitored according to Swedish legislation and REVAQ, a Swedish certification system for wastewater treatment plants (Persson et al. 2015). Plant nutrient concentrations were slightly higher for SS from Källby, e.g. $4.2 \% \mathrm{P}$ on average in dry matter sludge compared to $3.3 \% \mathrm{P}$ in Sjölunda.

During the 30-year period considered here (1981-2011), a total of 32 and $96 \mathrm{Mg} \mathrm{SS} \mathrm{ha}^{-1}$ was applied in treatments $\mathrm{B}$ and $\mathrm{C}$, respectively. Thus mean annual SS addition rate in the period was $32 / 30=1.07$ and $96 / 30=3.2 \mathrm{Mg} \mathrm{ha}^{-1}$. Assuming a $\mathrm{C}$ concentration of $31 \%$, as measured in SS applied in a similar experiment (Kätterer et al. 2011), this corresponds to 0.33 and $0.99 \mathrm{Mg} \mathrm{Cha}{ }^{-1} \mathrm{yr}^{-1}$ in treatments B and C, respectively.

The choice of crops follows the rotation applied on each farm, which is usually a 4-year rotation (Suppl. Table S1). Normal soil management practices for the area are performed, including mouldboard ploughing to $0.22-0.24 \mathrm{~m}$ depth. Crop spraying follows regional conventional standards. Straw and other non-crop materials are left on the soil surface. Due to low $\mathrm{pH}$, liming was carried out in 1998, with $6 \mathrm{Mg}$ limestone $\mathrm{ha}^{-1}$ at Igelösa and $4 \mathrm{Mg} \mathrm{ha}^{-1}$ at Petersborg, which caused the $\mathrm{pH}$ to increase from 6.6 in 1997 to $7.0-7.3$ in 2001 at Igelösa, and from 6.5-6.8 in 1997 to 7.2-7.4 in 2001 at Petersborg.

Chemical analyses

All chemical analyses, except when otherwise stated, are carried out by Eurofins, a commercial laboratory in Kristianstad, Sweden. Analyses of elements are performed regularly on samples of SS, soil and crops, and $\mathrm{pH}_{\mathrm{aq}}$ and concentration of ammonium-nitrogen $\left(\mathrm{NH}_{4}-\right.$ $\mathrm{N}$ ) and organic substances are determined (Andersson 2015). Soluble P is measured with the P-AL method, after extraction with $0.1 \mathrm{M}$ ammonium lactate and $0.4 \mathrm{M}$ acetic acid (Egnér et al. 1960). This is the method commonly used in Sweden as a proxy for plant-available $\mathrm{P}$ in soil.

Soil sampling in 2011

Soil samples for bulk density (BD) determination were taken in the plough layer at Petersborg on 26 May 
2011, 2 years after the latest SS application. Treatments with the highest and lowest $\mathrm{N}$ fertiliser level and highest and lowest SS dose were sampled, i.e. four treatments in total. Three cylinders $(100 \mathrm{~mm}$ high, $72 \mathrm{~mm}$ diameter) taken at about $0.07-0.17 \mathrm{~m}$ depth were assumed to be representative of the plough layer, which extends to about $0.23 \mathrm{~m}$ depth.

At the same time, soil cores were taken in the same four treatments. These soil cores were sliced into eight consecutive depth layers, to $0.225,0.25,0.275,0.30$, $0.35,0.40,0.50$ and $0.70 \mathrm{~m}$ depth. Five soil cores were taken in each plot and were then pooled to one composite sample per layer. Concentrations of total soil $\mathrm{C}$ and total $\mathrm{N}$ were determined by dry combustion (LECO CNS Analyzer; LECO Corporation, St Joseph MI 49085, USA).

\section{Soil carbon storage}

Soil organic carbon (SOC) stocks were estimated from BD and from SOC concentrations measured in all plots at both sites in autumn 2010 and 2011. For calculating SOC stocks to $0.20 \mathrm{~m}$ depth at Igelösa, the average SOC concentration per treatment from these two sampling occasions was used. For estimating topsoil $(0-0.20 \mathrm{~m})$ SOC stocks at Petersborg, the sampling from spring 2011 was also used for calculating average SOC concentration per treatment. For the four treatments at Petersborg, which were sampled to greater depth in spring 2011, SOC stocks were also calculated to $0.40 \mathrm{~m}$ equivalent depth (as described below).

A fixed depth was used for calculating SOC stocks in the topsoil, but we followed the equivalent mass concept which considers differences in BD between treatments (Ellert and Bettany 1995). The treatment with the lowest soil mass (C2) was taken as reference mass, in order to calculate the soil depth to which the same soil mass was distributed in the heavier soils. Thus, SOC stocks were calculated to $0.385 \mathrm{~m}$ depth in $\mathrm{A} 0,0.397 \mathrm{~m}$ in A2, $0.394 \mathrm{~m}$ in $\mathrm{C} 0$ and $0.400 \mathrm{~m}$ in C2. Otherwise, calculations corresponded to those described above for the topsoil.

At Petersborg, BD was measured in the four most extreme SS and $\mathrm{N}$ treatments (A0, A2, C0 and $\mathrm{C} 2$ ) to cover the full range of SOC and BD. Since BD was highly correlated with SOC, we used this relationship $\left(\mathrm{BD}=1.95-0.313 \times \mathrm{SOC} ; \mathrm{R}^{2}=0.904\right)$ for estimating $\mathrm{BD}$ of all treatments. For Igelösa, measured BD data were not available, so the value was estimated from a pedo-transfer function $(\mathrm{BD}=1.66-0.0767 \times$ SOC) derived from a Swedish database (Kätterer et al. 2006).

Gravel and stones were not measured. To avoid overestimation of SOC stocks (Poeplau et al. 2017), we assumed the fraction of coarse particles $(>2 \mathrm{~mm})$ to be $5 \%$ per volume according to our judgement and measurements for a nearby site (Wiklert et al. 1983). The carbon stocks at $0-0.20 \mathrm{~m}$ depth were then calculated as:

$$
\begin{aligned}
S O C_{\text {stock }}= & \text { SOC } \%_{\text {finesoil }} \times B D_{\text {finesoil }} \times \text { depth } \\
& \times\left(1-f_{\text {gravel }}\right)
\end{aligned}
$$

where $f_{\text {gravel }}$ is the volume fraction of gravel and stones, which was calculated from the mass of gravel and stones in the sample divided by an assumed rock density of $2.6 \mathrm{Mg} \mathrm{m}^{-3}$. The bulk density of the fine soil fraction $\left(B D_{\text {fine soil }}\right)$ was derived from the mass/ volume relationship in the bulk sample, corrected for the mass and volume of gravel and stones:

$B D_{\text {finesoil }}=\frac{\text { mass }_{\text {sample }}-\text { mass }_{\text {gravel }}}{\text { volume }_{\text {sample }}-\text { volume }_{\text {gravel }}}$

Assuming that changes in SOC stocks over time $(\triangle S O C)$ in the different treatments at each site solely were driven by carbon inputs, $\triangle S O C$ should be proportional to $\mathrm{C}$ input. However, due to differences in substrate quality, retention of $\mathrm{C}$ was assumed to differ between input sources. Since the pioneering work by Hénin and Dupuis (1945), the fraction of C input converted into soil organic material $(h)$ is referred to as 'humification coefficient' in many SOC models. It has been shown that $\mathrm{C}$ retention from root-derived $\mathrm{C}$ is higher than that from above-ground residues and that also SS has a different $\mathrm{C}$ retention coefficient (Kätterer et al. 2011, 2014). We considered this in a simple carbon mass balance approach by assigning different retention coefficients $\left(h_{j}\right)$ to the three categories of $\mathrm{C}$ input $\left(i_{j}\right)$ : above-ground residues, below-ground residues and SS:

$\triangle S O C=\triangle S O C_{0}+\sum_{j=1}^{j=3} h_{j} i_{j}$

where $\triangle S O C_{0}$ corresponds to $\triangle S O C$ at zero input and $\sum h_{j} i_{j}$ is the sum of all fractions $h_{j}$ of mean annual C input $i_{j}$ of corresponding category in each treatment. Since above- and below-ground $\mathrm{C}$ inputs were highly 
correlated in this study, we could not independently estimate their corresponding $h$-values. Instead, we used results from Kätterer et al. (2011) according to which $h$-values for below-ground inputs are 2.3 times higher than those for above-ground crop residues. The two remaining $h_{j}$-values for $\mathrm{C}$ input from sewage sludge and belowground crop residues were then estimated by simultaneously solving the system of nine equations per site (one for each treatment) by minimising root mean squared errors.

\section{Calculation of $\mathrm{C}$ inputs}

Crop-derived $\mathrm{C}$ inputs were estimated from grain yield dry mass, assuming a C concentration of $45 \%$. Net primary production (NPP) was calculated from crop yield in each treatment as described by Bolinder et al. (2007) and then allocation coefficients were used (Table 2) for calculating $\mathrm{C}$ inputs from above- and below-ground crop residues. Based on Kätterer et al. (2011), it was assumed that $71 \%$ of below-ground inputs were deposited in the topsoil.

\section{Statistical treatments}

Replicate samples ( $\mathrm{n}=4$ for each treatment) have been treated individually if they have been available. SAS software (SAS Institute, Inc., Cary, NC, software release 9.4) was used for analysis of variance, which was conducted to analyse treatment effects on yield and soil C per depth layer. Post-hoc (LSD) tests were applied to assess differences between treatments.

Table 2 Allocation coefficient of net primary production to harvested product $(\mathrm{Rp})$, shoots (Rs) and roots ( $\mathrm{Rr}$; including rhizodeposition) for the major crops grown at the two sites

\begin{tabular}{llll}
\hline Grain & $\mathrm{Rp}$ & $\mathrm{Rs}$ & $\mathrm{Rr}$ \\
\hline Oilseed rape $^{1}$ & 0.154 & 0.541 & 0.306 \\
Winter wheat $^{2}$ & 0.322 & 0.482 & 0.196 \\
Sugar beet $^{3}$ & 0.626 & 0.357 & 0.017 \\
Spring cereals $^{2}$ & 0.451 & 0.400 & 0.149 \\
\hline
\end{tabular}

According to ${ }^{1}$ Gan et al. (2009), ${ }^{2}$ Bolinder et al. (2007) and ${ }^{3}$ Bolinder et al. (2015)

\section{Results}

Yields

Yields were higher than normal in the region during the study period, with winter wheat yield exceeding $12 \mathrm{Mg} \mathrm{ha}^{-1}$ at both sites in 2014 and 2015, while in 2013 Igelösa had barley yield of $8.85 \mathrm{Mg} \mathrm{ha}^{-1}$ (with the highest values in treatment $\mathrm{C} 2$ ). The normalised yield values showed that mineral fertiliser had a much greater impact on yield than SS (Table 1). Even the half dose of mineral $\mathrm{N}$ gave a greater increase in yield than the highest dose of SS. The yield response to both mineral fertiliser and SS application was generally higher at Petersborg than at Igelösa. Time elapsed since SS application had no effect on yield.

On examining the change in yield over time, a weak positive effect ( $p=0.056)$ due to SS application was seen at Petersborg when comparing the high SS application with no fertilisation (Fig. 1a), while addition of mineral fertilisation decreased this effect (Fig. 1b). No such effect was observed in Igelösa. As can be seen from Fig. 1a, b, the effect also varied among crops. For example, yield of sugar beet did not change over time, whereas relative yield of winter wheat and particularly of barley increased with time due to SS application (Fig. 2). However, these effects were minor compared with the effects of mineral fertiliser application, where the response value, calculated as the ratio in yields between the A2 and A0 treatments was 2.26 at Petersborg and 1.99 at Igelösa.

\section{Nitrogen}

The N content in SS varied between 3.1 and $4.8 \%$ of $\mathrm{DM}$ at Petersborg and between 2.4 and $5.5 \%$ of DM at Igelösa. This means that with a dose of $12 \mathrm{Mg}$ DM SS $\mathrm{ha}^{-1}$, around $0.4 \mathrm{Mg} \mathrm{N}^{-1}$ were added, which corresponds to about $0.1 \mathrm{Mg} \mathrm{N}^{-1}$ as an annual mean. However, the yield response to this $\mathrm{N}$ from SS was much lower than that from mineral fertilisation (Table 1). Estimates of the $\mathrm{N}$ use efficiency also showed that the value of SS as $\mathrm{N}$ fertiliser was very limited or less than $10 \%$ (Table 3).

Phosphorus

Soil P content (P-AL) increased significantly with SS dose at both sites (Fig. 3). Based on the annual change 
(a)

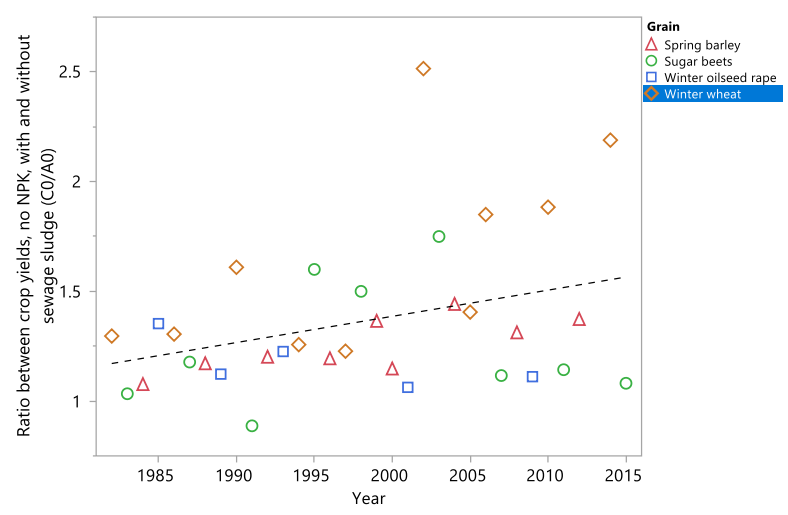

Fig. 1 Crop yields at Petersborg over time in: a the treatment with the highest application rate of sewage sludge (SS) (treatment C) compared with the treatment without SS (treatment A), both without mineral fertilisers, $\mathrm{R}^{2}=0.113$;

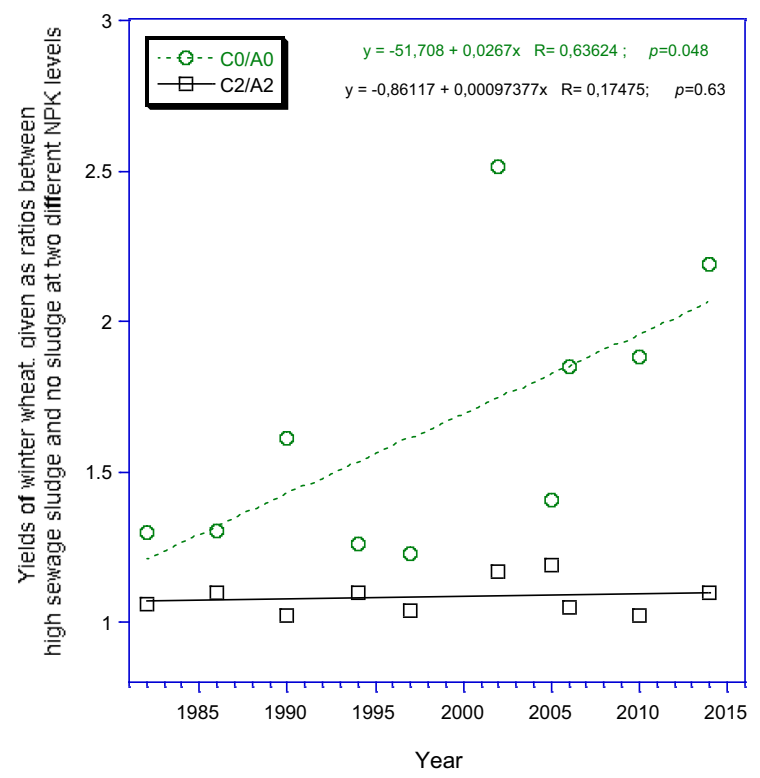

Fig. 2 Relative yield of winter wheat (left panel) and spring barley (right panel) over time at Petersborg in the treatment with the highest application rate of sewage sludge (SS) (treatment C)

over time and bulk density, we calculated the change in topsoil P-AL stocks and compared this with the total $\mathrm{P}$ content, which can be expected to remain stable in soil according to the P-balance, calculated as the difference between applied $\mathrm{P}$ (mineral fertilisers and SS) and $\mathrm{P}$ amounts removed with crop harvest (data in Table 4). This comparison showed that $P$ recovered in the P-AL extract corresponded to 2.6 and $2.2 \%$ of net $\mathrm{P}$ (b)

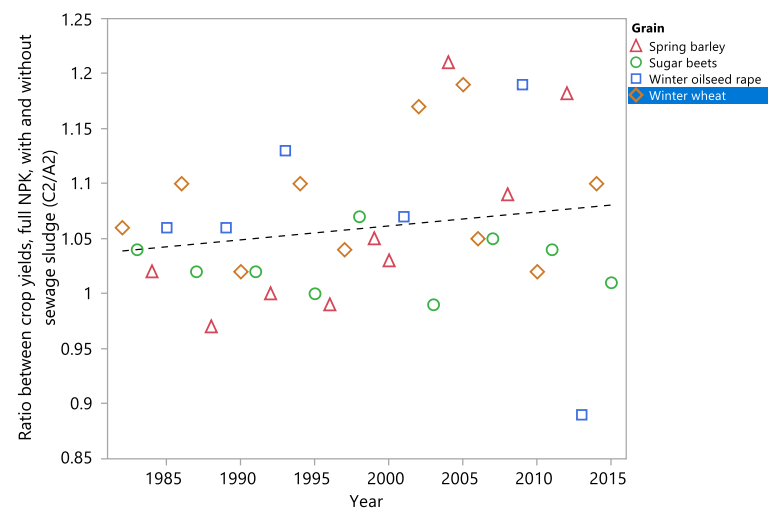

$p=0.056$; b plots amended with $12 \mathrm{Mg}$ DM SS every 4 years compared with plots with no SS, where all plots received full mineral fertilisation. $\mathrm{R}^{2}=0.033 ; p=0.31$

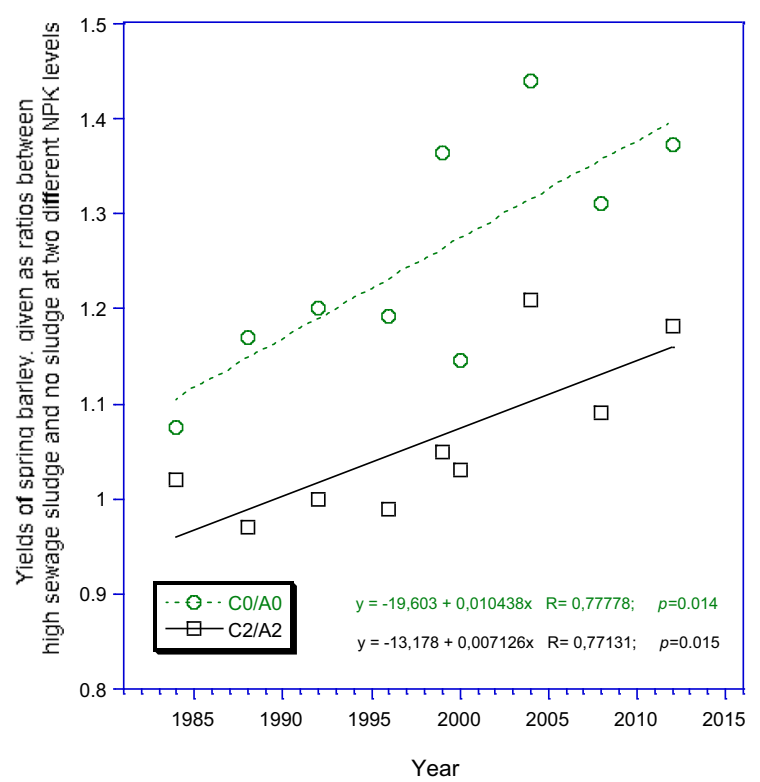

compared with in the treatment without SS (treatment A) at the lowest (treatment 0 ) and highest (treatment 2) rate of mineral fertilisation

deposits at Igelösa and Petersborg, respectively (Fig. 4).

\section{Bulk density}

Bulk density measured in spring 2011 in the Petersborg topsoil was significantly lower in treatments A2 $\left(1.59 \mathrm{Mg} \mathrm{m}^{-3}\right)$ and $\mathrm{C} 2\left(1.56 \mathrm{Mg} \mathrm{m}^{-3}\right)$ than in the unfertilised treatment $\mathrm{A} 0\left(1.68 \mathrm{Mg} \mathrm{m}^{-3}\right)$ and also 
Table 3 Nitrogen $(\mathrm{N})$ use efficiency for the nine treatments with/without mineral nitrogen $(\mathrm{N})$ fertiliser and sewage sludge (SS) at the two sites; annual mean values for the period
1981-2013 based on the difference calculation $\left(\mathrm{N} \mathrm{removal}\right.$ treatment $\left.-\mathrm{N} \mathrm{removal} \mathrm{l}_{\text {control }}\right) / \mathrm{N}_{\text {input }} \times 100$

\begin{tabular}{|c|c|c|c|c|c|c|}
\hline $\begin{array}{l}\text { Site } \\
\text { Treatment }\end{array}$ & $\begin{array}{l}\text { Mineral N } \\
\text { applied } \\
\left(\mathrm{kg} \mathrm{ha}^{-1} \mathrm{yr}^{-1}\right)\end{array}$ & $\begin{array}{l}\text { SS N applied } \\
\left(\mathrm{kg} \mathrm{ha}^{-1} \mathrm{yr}^{-1}\right)\end{array}$ & $\begin{array}{l}\mathrm{N} \text { removed } \\
\text { with crops } \\
\left(\mathrm{kg} \mathrm{ha}^{-1} \mathrm{yr}^{-1}\right)\end{array}$ & $\begin{array}{l}\mathrm{N} \text { derived } \\
\text { from SS } \\
\left(\mathrm{kg} \mathrm{ha}^{-1} \mathrm{yr}^{-1}\right)\end{array}$ & $\begin{array}{l}\mathrm{N} \text { use } \\
\text { efficiency } \\
(\%)\end{array}$ & $\begin{array}{l}\text { SS N use } \\
\text { efficiency } \\
(\%)\end{array}$ \\
\hline \multicolumn{7}{|l|}{ Petersborg } \\
\hline A0. No SS, No N & 0 & 0 & 37 & & - & \\
\hline A1. No SS, half $\mathrm{N}$ & 68 & 0 & 71 & & 50 & \\
\hline A2. No SS, full $\mathrm{N}$ & 129 & 0 & 99 & & 48 & \\
\hline B0. $1 \mathrm{Mg}$ DM SS ha ${ }^{-1} \mathrm{yr}^{-1}$, no N & 0 & 36 & 44 & 7 & 19 & 19 \\
\hline $\begin{array}{l}\text { B1. } 1 \mathrm{Mg} \text { DM SS ha }{ }^{-1} \mathrm{yr}^{-1} \text {, half } \\
\end{array}$ & 68 & 36 & 78 & 7 & 39 & 19 \\
\hline B2. $1 \mathrm{Mg} \mathrm{DM} \mathrm{SS} \mathrm{ha}^{-1} \mathrm{yr}^{-1}$, full $\mathrm{N}$ & 129 & 36 & 104 & 5 & 41 & 14 \\
\hline C0. $3 \mathrm{Mg}$ DM SS ha ${ }^{-1} \mathrm{yr}^{-1}$, no N & 0 & 107 & 51 & 14 & 13 & 7 \\
\hline $\begin{array}{l}\text { C1. } 3 \mathrm{Mg} \text { DM SS ha }{ }^{-1} \mathrm{yr}^{-1} \text {, half } \\
\mathrm{N}\end{array}$ & 68 & 107 & 83 & 12 & 26 & 5 \\
\hline \multicolumn{7}{|l|}{ Igelösa } \\
\hline A0. No SS, No N & 0 & 0 & 43 & & - & \\
\hline A1. No SS, half $\mathrm{N}$ & 69 & 0 & 68 & & 36 & \\
\hline A2. No SS, full $\mathrm{N}$ & 132 & 0 & 94 & & 39 & \\
\hline B0. $1 \mathrm{Mg}$ DM SS ha ${ }^{-1} \mathrm{yr}^{-1}$, no N & 0 & 34 & 48 & 5 & 15 & 15 \\
\hline $\begin{array}{l}\text { B1. } 1 \mathrm{Mg} \text { DM SS ha }{ }^{-1} \mathrm{yr}^{-1} \text {, half } \\
\text { N }\end{array}$ & 69 & 34 & 75 & 7 & 31 & 21 \\
\hline B2. $1 \mathrm{Mg} \mathrm{DM} \mathrm{SS} \mathrm{ha}^{-1} \mathrm{yr}^{-1}$, full $\mathrm{N}$ & 132 & 34 & 98 & 4 & 33 & 12 \\
\hline C0. $3 \mathrm{Mg}$ DM SS ha ${ }^{-1} \mathrm{yr}^{-1}$, no N & 0 & 103 & 59 & 16 & 16 & 11 \\
\hline $\begin{array}{l}\text { C1. } 3 \mathrm{Mg} \mathrm{DM} \mathrm{SS} \mathrm{ha}{ }^{-1} \mathrm{yr}^{-1} \text {, half } \\
\mathrm{N}\end{array}$ & 69 & 103 & 82 & 14 & 23 & 7 \\
\hline C2. $3 \mathrm{Mg} \mathrm{DM} \mathrm{SS} \mathrm{ha}^{-1} \mathrm{yr}^{-1}$, full $\mathrm{N}$ & 132 & 103 & 105 & 11 & 26 & 7 \\
\hline
\end{tabular}

significantly ( $p=0.023$ ) lower on average in the two $\mathrm{N}$-fertilised treatments (A2 and $\mathrm{C} 2 ; 1.57 \mathrm{Mg} \mathrm{m}^{-3}$ ) compared with the non $\mathrm{N}$-fertilised treatments (A0 and $\mathrm{C} 0 ; 1.64 \mathrm{Mg} \mathrm{m}^{-3}$ ) (Suppl. Table S2). Gravimetric water content measured in the same samples was significantly higher in the $\mathrm{N}$-fertilised compared with the non $\mathrm{N}$-fertilised treatments $(p=0.029$; Table 5).

SOC concentrations along the profile

The SS amendments caused a general increase in SOC at both at Petersborg and Igelösa (Fig. 5 and Suppl. Table S3). At Petersborg, SOC concentration in the soil profile (depth layers 0-0.225, 0.225-0.25, $0.25-0.275$ and $0.275-0.30 \mathrm{~m}$ ) was significantly higher in the SS-amended treatment than in the corresponding $\mathrm{N}$-fertilised or unfertilised treatments
(Fig. 5). Nitrogen fertilisation also increased SOC compared with the non $\mathrm{N}$-fertilised treatments, but the effect was only significant in soil layers to $0.275 \mathrm{~m}$ depth.

\section{Carbon balance}

According to the estimated retention coefficient $h_{j}$ for SS, C retention from SS in the topsoil $(0-0.20 \mathrm{~m})$ varied between 11 and $20 \%$ at the two sites (Table 5). Site differences were probably due to SS quality, which differed between sites. The higher clay content at Igelösa could also be a possible explanation for the higher retention at this site. Retention of above-ground crop residues was similar at both sites, i.e. 4.5 and $4.9 \%$ at Igelösa and Petersborg, respectively (Table 3). At Petersborg, where the layers below the 
Fig. 3 Change in ammonium lactateextractable phosphorus $(\mathrm{P}-$ $\mathrm{AL})$ in the topsoil over time in all treatments at the two sites. Dotted line $=$ zero $\mathrm{N}$, punctuated lines $=$ half $\mathrm{N}$, solid lines $=$ full $\mathrm{N}$

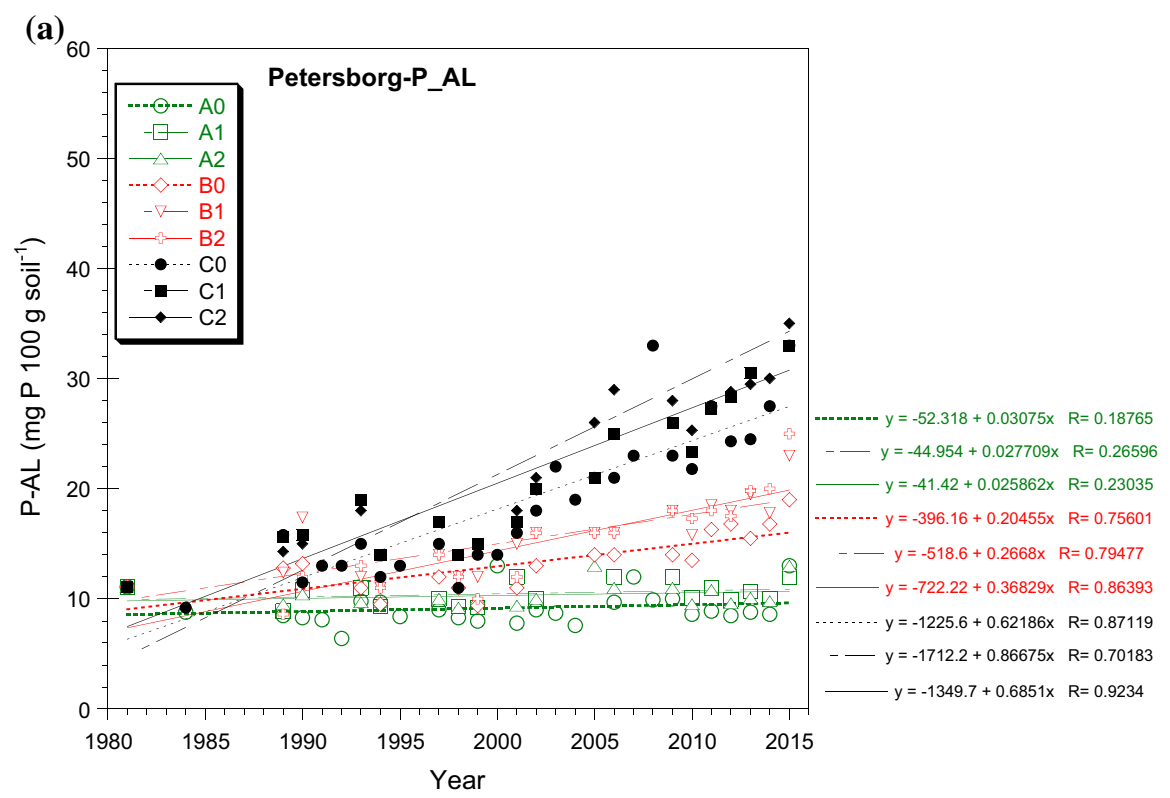

(b)

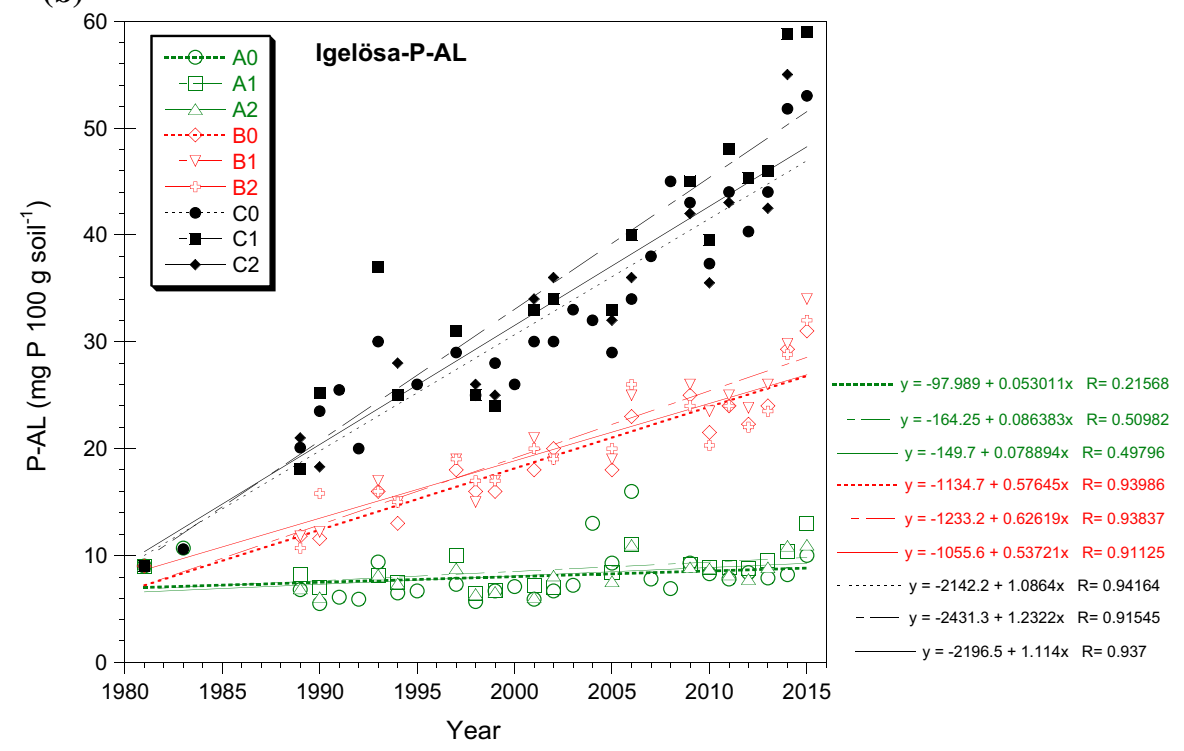

topsoil were also studied, the retention coefficient for SS increased to $18 \%$ for the $0-0.40 \mathrm{~m}$ layer (Table 5). The performance of the simple $\mathrm{C}$ balance model was generally good, yielding high $\mathrm{R}^{2}$ values for both sites (Fig. 6).

After 30 years, SOC stocks in the $0-0.20 \mathrm{~m}$ layer at Petersborg were 4.0 or $4.8 \mathrm{Mg} \mathrm{ha}^{-1}$ higher in SSamended than in unamended treatments in the non $\mathrm{N}$-fertilised and $\mathrm{N}$-fertilised treatment, respectively. The corresponding increase at $0-0.40 \mathrm{~m}$ depth was 5.9 and $9.1 \mathrm{Mg} \mathrm{ha}^{-1}$, respectively (Table 6). Thus, as much as 32 and $47 \%$ of the SOC changes due to SS addition occurred in the $0.20-0.40 \mathrm{~m}$ soil layer in the non $\mathrm{N}$-fertilised and $\mathrm{N}$-fertilised treatment, respectively. Besides direct $\mathrm{C}$ retention from $\mathrm{SS}$, these estimates also include SS-induced increases in C inputs from crop residues (mainly roots), due to enhanced crop production resulting from SS-derived nutrients and improved physical soil structure (Fig. 7).

Nitrogen fertilisation also increased SOC content in the SS-amended and non-amended treatments (Fig. 7). At Petersborg, the mean SOC increase due 
Table 4 Phosphorus $(\mathrm{P})$ balance in topsoil $(0-0.20 \mathrm{~m})$ for the period 1981-2013 in the nine treatments with/without mineral nitrogen $(\mathrm{N})$ fertiliser and sewage sludge (SS) at the two sites

\begin{tabular}{|c|c|c|c|c|}
\hline $\begin{array}{l}\text { Site } \\
\text { Treatment }\end{array}$ & $\begin{array}{l}\text { Mineral P } \\
\text { applied }\end{array}$ & $\begin{array}{l}\text { SS P } \\
\text { applied }\end{array}$ & $\begin{array}{l}\text { P removed } \\
\text { with crops }\end{array}$ & $\begin{array}{l}\Delta \mathrm{P}=\text { applied }- \\
\text { removed with crops }\end{array}$ \\
\hline \multicolumn{5}{|l|}{ Petersborg } \\
\hline A0. No SS, No N & 0 & 0 & 10 & -10 \\
\hline A1. No SS, half $\mathrm{N}$ & 22 & 0 & 17 & 5 \\
\hline A2. No SS, full N & 22 & 0 & 12 & 2 \\
\hline B0. $1 \mathrm{Mg}$ DM SS ha ${ }^{-1} \mathrm{yr}^{-1}$, no N & 0 & 34 & 11 & 23 \\
\hline B1. $1 \mathrm{Mg}$ DM SS ha ${ }^{-1} \mathrm{yr}^{-1}$, half $\mathrm{N}$ & 22 & 34 & 18 & 38 \\
\hline B2. $1 \mathrm{Mg}$ DM SS ha ${ }^{-1} \mathrm{yr}^{-1}$, full $\mathrm{N}$ & 22 & 34 & 18 & 36 \\
\hline C0. $3 \mathrm{Mg} \mathrm{DM} \mathrm{SS} \mathrm{ha}{ }^{-1} \mathrm{yr}^{-1}$, no $\mathrm{N}$ & 0 & 101 & 12 & 89 \\
\hline C1. $3 \mathrm{Mg}$ DM SS ha ${ }^{-1} \mathrm{yr}^{-1}$, half $\mathrm{N}$ & 22 & 101 & 18 & 105 \\
\hline $\begin{array}{l}\text { C2. } 3 \mathrm{Mg} \text { DM SS ha }{ }^{-1} \mathrm{yr}^{-1} \text {, full } \mathrm{N} \\
\text { Igelösa }\end{array}$ & 22 & 101 & 20 & 103 \\
\hline A0. No SS, No N & 0 & 0 & 12 & -12 \\
\hline A1. No SS, half $\mathrm{N}$ & 20 & 0 & 18 & 1 \\
\hline A2. No SS, full N & 20 & 0 & 22 & -2 \\
\hline B0. $1 \mathrm{Mg}$ DM SS ha ${ }^{-1} \mathrm{yr}^{-1}$, no N & 0 & 34 & 14 & 27 \\
\hline B1. $1 \mathrm{Mg}$ DM SS ha ${ }^{-1} \mathrm{yr}^{-1}$, half $\mathrm{N}$ & 20 & 34 & 20 & 41 \\
\hline B2. $1 \mathrm{Mg}$ DM SS ha ${ }^{-1} \mathrm{yr}^{-1}$, full $\mathrm{N}$ & 20 & 34 & 23 & 38 \\
\hline C0. $3 \mathrm{Mg} \mathrm{DM} \mathrm{SS} \mathrm{ha}{ }^{-1} \mathrm{yr}^{-1}$, no $\mathrm{N}$ & 0 & 103 & 16 & 107 \\
\hline C1. $3 \mathrm{Mg}$ DM SS ha ${ }^{-1} \mathrm{yr}^{-1}$, half $\mathrm{N}$ & 20 & 103 & 21 & 122 \\
\hline C2. $3 \mathrm{Mg}$ DM SS ha $^{-1} \mathrm{yr}^{-1}$, full $\mathrm{N}$ & 20 & 103 & 23 & 119 \\
\hline
\end{tabular}

Values correspond to $\mathrm{kg} \mathrm{P} \mathrm{ha}^{-1} \mathrm{yr}^{-1}$

to nitrogen fertilisation was $6.2 \mathrm{Mg} \mathrm{ha}^{-1}$ to $0.20 \mathrm{~m}$ and $8.1 \mathrm{Mg} \mathrm{ha}^{-1}$ to $0.40 \mathrm{~m}$ depth when no SS was applied, while it was $7.0 \mathrm{Mg} \mathrm{ha}^{-1}$ to $0.20 \mathrm{~m}$ and $11.3 \mathrm{Mg} \mathrm{ha}^{-1}$ to $0.40 \mathrm{~m}$ when SS was applied (Table 6).

Heavy metals in soil and grain

On scrutinising all data, it was found that SS caused accumulation of only three heavy metals [copper $(\mathrm{Cu})$, mercury $(\mathrm{Hg})$ and zinc $(\mathrm{Zn})]$ out of 14 elements analysed in the soils. Copper in the soil with the highest SS level at Igelösa showed an increase from around $12 \mathrm{mg} \mathrm{Cu} \mathrm{kg}^{-1}$ soil $\left(\mathrm{HNO}_{3}\right.$-extract) to around $25 \mathrm{mg} \mathrm{Cu} \mathrm{kg}^{-1}$ soil during the study period (Fig. 8a). However, it should be noted that there were two obvious phases, with an initial rapid increase in concentrations and then stabilisation after the early 1990s. A similar effect was observed for $\mathrm{Hg}$ at Igelösa, i.e. stabilisation after a doubling during the early phase (Fig. 8b). Concentrations of other metals, including cadmium $(\mathrm{Cd})$ and lead $(\mathrm{Pb})$, have not changed significantly over time. Cadmium appeared to reach a small peak in 1994 at $0.44 \mathrm{mg} \mathrm{kg}^{-1}$ soil in samples from treatments with the highest SS application rates at Igelösa, but since then the concentration has always been below $0.40 \mathrm{mg} \mathrm{Cd} \mathrm{kg}^{-1}$ soil $\left(\mathrm{HNO}_{3}\right.$-extract). At Petersborg, the $\mathrm{Cd}$ level has remained quite steady at around 0.30 during the whole study period, without any difference between treatments. As reported by Andersson (2015), SS application has not affected absorption of heavy metals into the crop.

\section{Discussion}

Yield

At the Petersborg site, SS application tended to increase crop yield over time during the study period, but when plant nutrients were not limiting the effect was only significant for spring barley (Figs. 1, 2). 


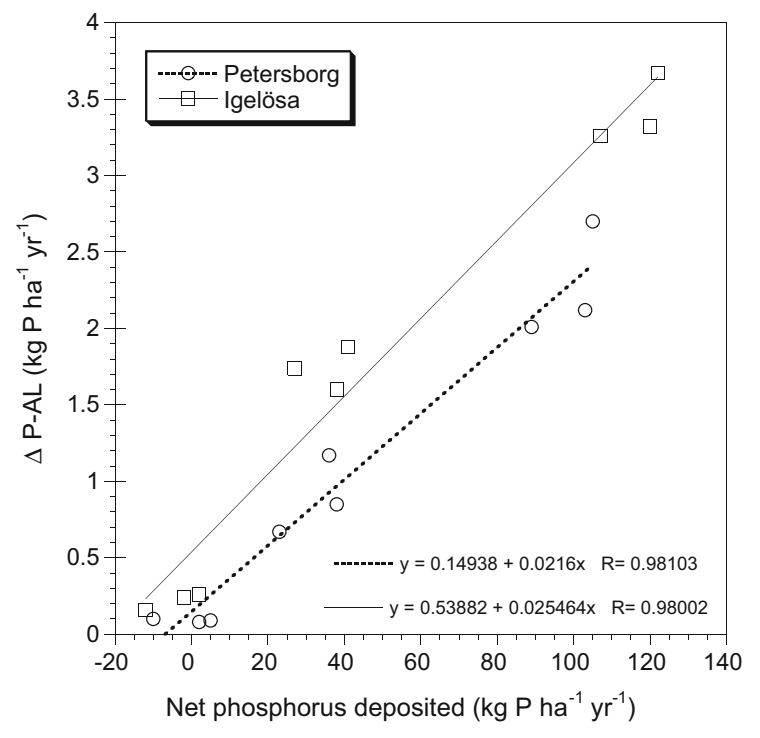

Fig. 4 Mean annual change in ammonium lactate-extractable phosphorus (P-AL) in topsoil $(0-0.20 \mathrm{~m})$ as a function net amount of $\mathrm{P}$ deposited per hectare and year

Improved soil structure could have been the main driver for this fertility enhancement after SS application, as indicated by lower bulk density and higher soil $\mathrm{C}$ concentrations in SS-treated soil. Improvement in soil physical properties may be more important for production than the nutrient content of SS (Antoniadis et al. 2015). This effect was not observed at Igelösa, probably because the SOC level was higher at that site $(4.3 \%)$ than at Petersborg (1.7\%) at the beginning of the experiment, due to different land use history.

\section{Nitrogen}

Low $\mathrm{N}$ use efficiency for SS was observed in the two trials and has been reported earlier (Kirchmann et al. 2017). As Table 3 shows, the $\mathrm{N}$ in SS only contributed a few percent to plant production. Rigby et al. (2016) reviewed the nitrogen fertiliser value of biosolids, using a large number of publications, and found that the average use efficiency of $\mathrm{N}$ in SS declined with the degree of stabilisation and that after mesophilic anaerobic digestion, the mean proportion of mineralisable N was $30 \%$. Rigby et al. (2016) also concluded that almost "all of the agronomically significant $\mathrm{N}$ was released in the year of application", although some residual effects could be found the second season in temperate regions.

\section{Phosphorus}

Our finding that only around $2 \%$ of the $\mathrm{P}$ in topsoil was extractable with the P-AL method, regardless of the amount of $\mathrm{P}$ remaining in soil and the proportion of extractable $\mathrm{P}$ in this residual $\mathrm{P}$, is somewhat surprising. However, it is consistent with recent findings in Denmark, where the fertiliser value of SS treated with iron was found to be zero (Müller-Stöver et al. 2018). The claim by Mackay et al. (2017) that P may be slowly released from SS over a long time thus appears uncertain.

Nawara et al. (2017) compared different methods, including P-AL, for soil $\mathrm{P}$ analysis in a large number of samples from different agricultural soils in Europe and obtained critical values for P-AL (95\% yield) for many crops, such as wheat $\left(6.9 \mathrm{mg}\right.$ P-AL $100 \mathrm{~g}^{-1}$ soil), barley $7.5 \mathrm{mg}$ P-AL $100 \mathrm{~g}^{-1}$ soil), sugar beet (7.7 mg P-AL $100 \mathrm{~g}^{-1}$ soil) and potato $(20 \mathrm{mg}$ P-AL $100 \mathrm{~g}^{-1}$ soil). At the normal dose of SS in the trials at Igelösa and Petersborg, these levels were achieved. However, our analysis indicated very low $\mathrm{P}$ availability for plants. Pre-treatment of SS is of utmost importance for $\mathrm{P}$ availability for plants, and precipitation with $\mathrm{FeCl}_{3}$ results in strong chemical bonds between iron and phosphate. Vogel et al. (2017) compared different treatments of SS prior to fertilisation and found that treatment with $\mathrm{MgCl}_{2}$ in thermochemical treatment or under oxidising air only resulted in $6.5 \%$ and $26 \% \mathrm{P}$ uptake, respectively, in maize plants compared with triple superphosphate. $\mathrm{Xu}$ et al.

Table 5 Estimated retention factors of the three different carbon $(C)$ input sources

\begin{tabular}{llll}
\hline & Above-ground crop residues & Below-ground crop residues & Sewage sludge \\
\hline Petersborg 0-0.20 m & 0.049 & 0.133 & 0.111 \\
Petersborg 0-0.40 m & 0.095 & 0.214 & 0.183 \\
Igelösa 0-0.20 m & 0.045 & 0.104 & 0.201 \\
\hline
\end{tabular}




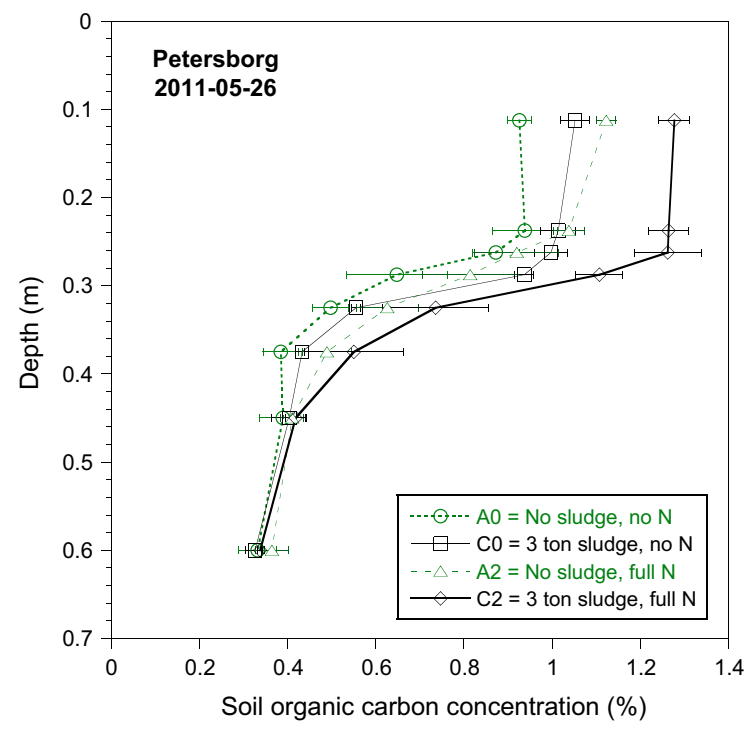

Fig. 5 Soil organic carbon (SOC) concentration down the soil profile in sewage sludge-amended treatments and nitrogen (N) fertilised and non $\mathrm{N}$-fertilised treatments at Petersborg, measured in May 2011. Error bars are SE for $n=4$

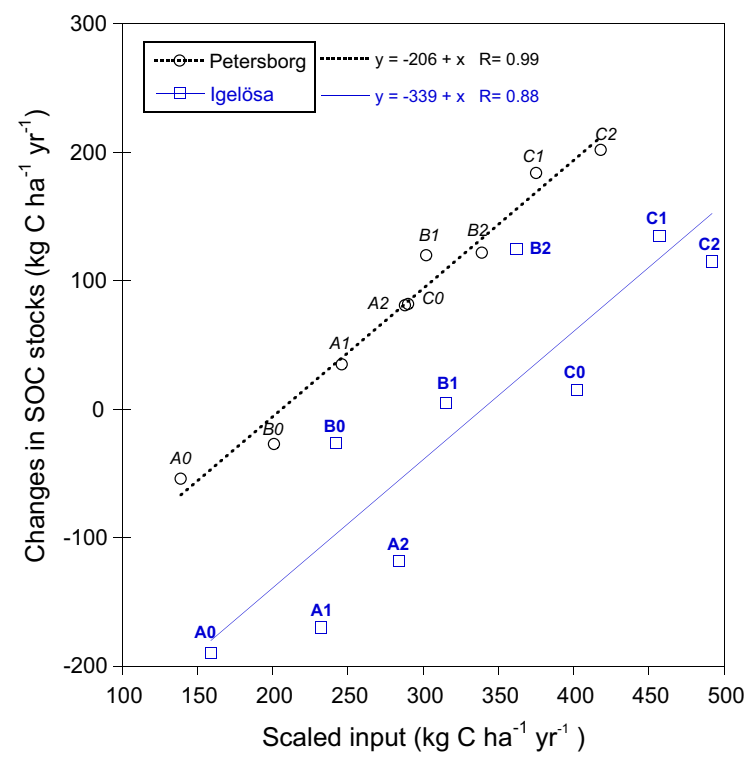

Fig. 6 Changes in soil organic carbon (SOC) stocks to $0.20 \mathrm{~m}$ depth in the nine treatments at Petersborg and Igelösa, as a function of scaled carbon inputs according to Eq. 1

(2012) performed sequential extractions with SS samples from China and found that $2.6-15.8 \%$ of total $\mathrm{P}$ was extractable in $\mathrm{NH}_{4} \mathrm{Cl}$ but that only around $60 \%$ could be extracted with $\mathrm{HCl}$. The lower values
Table 6 Accumulated soil organic carbon (SOC) to 0.20 or $0.40 \mathrm{~m}$ equivalent depth $\left(\mathrm{Mg} \mathrm{C} \mathrm{ha}^{-1}\right)$ at Petersborg

\begin{tabular}{lllll}
\hline Equiv. depth (m) & A0 & A2 & C0 & C2 \\
\hline $0-0.20$ & 28.1 & 33.9 & 31.8 & 38.5 \\
$0-0.40$ & 49.2 & 57.0 & 54.9 & 66.2 \\
\hline
\end{tabular}

could be linked to treatment processes involving iron (Fe) and aluminium (Al).

\section{Soil carbon}

Elevated concentrations of SOC in topsoil as an effect of SS application have been reported earlier for both our field trial sites by Börjesson et al. (2014), who concluded that microbial biomass is highly correlated with SOC and thus independent of treatment-specific substrates for decomposers. This proportionality between SOC and microbial biomass may have changed with changes in SS properties over time, as shown in other studies. For example, a change in the quality of SS as indicated by microbiological activity was observed by Gibbs et al. (2006) in the UK on comparing their results with values reported in the 1980s. A decrease in the concentration of heavy metals over time may have increased SS decomposability, leading to higher biomass and lower retention of SS-derived C. According to our C balance calculations, between 11 and $20 \%$ of total C applied with SS was retained in the upper $0.20 \mathrm{~m}$ of the soil at the two sites (Table 5). These retention coefficients were lower than those found for SS applied at two other Swedish sites on clay soils (Kätterer et al. 2011, 2014), probably due to differences in SS quality and soil properties. Our estimated retention coefficients for crop residues, i.e. $4.5-4.9 \%$ for above-ground residues (Table 5), were also lower than those reported by Kätterer et al. (2011, 2014), but in line with findings in other Swedish studies showing an increase in $\mathrm{C}$ retention from above-ground crop residues with clay content (Poeplau et al. 2015).

In order to compare $\mathrm{C}$ retention efficacy in different soils, several other variables such SS quantity and quality have to be considered. Tian et al. (2009) calculated $\mathrm{C}$ sequestration using data from a long-term field experiment series in the US where SS had been applied for up to 34 years on 41 fields. According to 

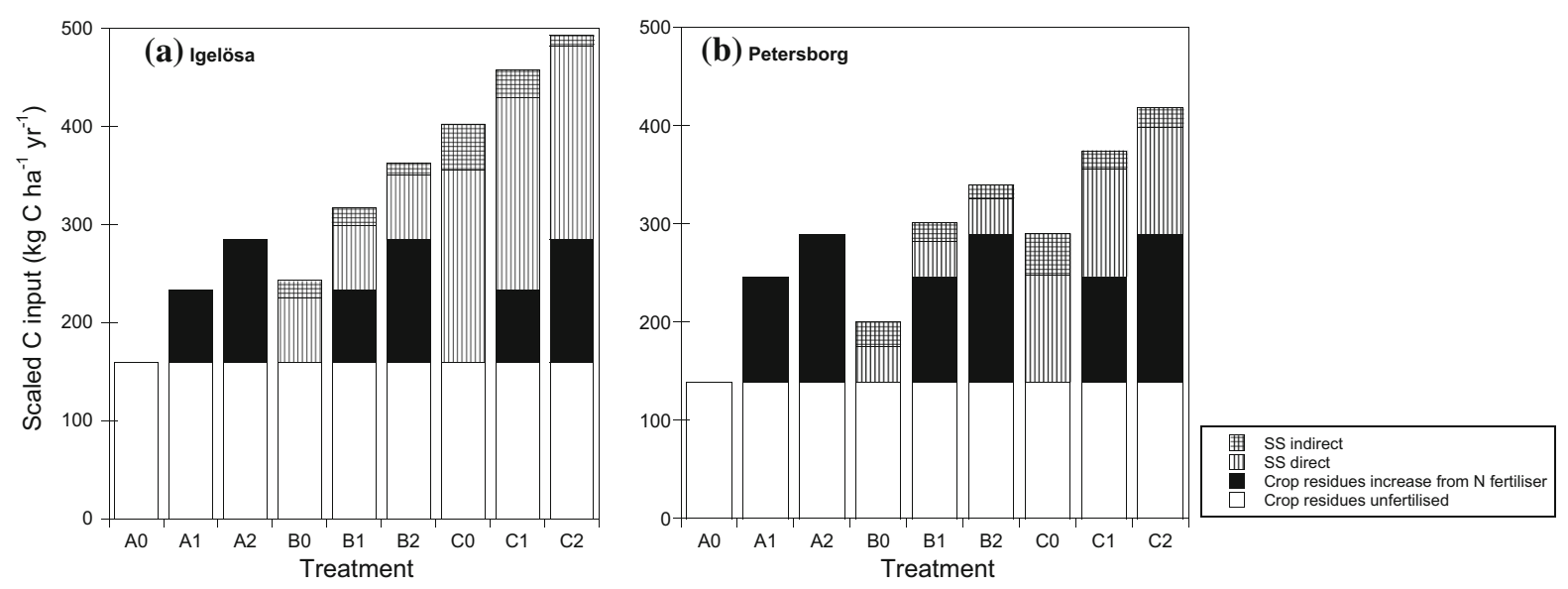

Fig. 7 Retention of carbon (C) from different $C$ input sources in topsoil in the nine treatments at a Igelösa and $\mathbf{b}$ Petersborg

their calculations, SOC stocks increased by $64 \mathrm{~kg}$ for each $\mathrm{Mg}(\mathrm{DM})$ of SS applied. Assuming that the SS contained $35 \% \mathrm{C}$, this would correspond to $18 \%$ efficiency for the whole scale of application rates (13-49 $\mathrm{Mg} \mathrm{C} \mathrm{ha}^{-1} \mathrm{yr}^{-1}$ ), which is within the range estimated for the Swedish sites in the present study.

In a field experiment with a SS-amended clay soil cropped with maize in Brazil (Pitombo et al. 2015), two different doses (10 and $20 \mathrm{Mg} \mathrm{DM} \mathrm{ha}{ }^{-1} \mathrm{yr}^{-1}$ with $27.9 \% \mathrm{C}$ in SS DM, corresponding to 2.79 and $5.58 \mathrm{Mg} \mathrm{ha}^{-1} \mathrm{yr}^{-1}$ ) were applied annually during 7 years, supplying a total amount of $19.5 \mathrm{Mg}$ and $39.1 \mathrm{Mg} \mathrm{C} \mathrm{ha}{ }^{-1}$, respectively. The increase in soil C stocks down to $0.40 \mathrm{~m}$ depth was determined to be (72.5-control 58.8) $=13.7 \mathrm{Mg} \mathrm{Cha}^{-1}$ and $(83.1-58.8)=24.3 \mathrm{MgC} \mathrm{ha}^{-1}$, respectively. Efficiency was thus $13.7 / 19.5=70 \%$ and 24.3 / $39.1=62 \%$, respectively.

In the Ultuna long-term trial in Sweden, where SS has been applied continuously since 1956, around $41 \%$ of the carbon added with the SS is estimated to have been stabilised in soil (Kätterer et al. 2011).

Calleja-Cervantes et al. (2017) report results from experiments in Spain that have been running since 1992 and fertilised with thermophilic digested SS at rates up to $80 \mathrm{Mg} \mathrm{ha}^{-1} \mathrm{yr}^{-1}$. Their results show that $\mathrm{SS}$ can induce $\mathrm{C}$ sequestration without increasing greenhouse gas emissions.
Metals in soil

Accumulation of heavy metals in the soils of our study sites has been limited. There also seems to be considerable attenuation with time and some elements could have been translocated to deeper soil layers. Cadmium can be transported down through the soil profile, as shown by Bergkvist et al. (2003). The lower $\mathrm{Cd}$ values at Petersborg compared with Igelösa could be explained by the lower clay content, which could increase mobility. A previous study has also shown that the concentration of heavy metals in Swedish SS has declined substantially over the years (Kirchmann et al. 2017). Copper has been a problem earlier at the Igelösa and Petersborg sites, but $\mathrm{Cu}$ concentrations in SS dropped from 2000 down to below $500 \mathrm{mg} \mathrm{Cu} \mathrm{kg} \mathrm{DM}^{-1}$ after 1999, to a large extent due to changes in drinking water resources and removal of old copper pipes (Andersson 2015).

Smolders and Six (2013) calculated the mass balance for $\mathrm{Cd}$ in European soils and found that $\mathrm{Cd}$ has decreased in recent years owing to a considerable decrease in $\mathrm{Cd}$ concentrations in precipitation. This means that when using normal fertilisation, it would take high $\mathrm{Cd}$ concentrations in phosphate (80 mg Cd kg ${ }^{-1} \mathrm{P}_{2} \mathrm{O}_{5}$ ) to maintain the same concentration as previously. This of course also depends on the application rates; the use of $\mathrm{P}$ fertilisers in the $\mathrm{EU}$ has decreased, from $77 \mathrm{~kg} \mathrm{P}_{2} \mathrm{O}_{5} \mathrm{ha}^{-1} \mathrm{yr}^{-1}$ in 1980 to $35 \mathrm{~kg} \mathrm{P}_{2} \mathrm{O}_{5} \mathrm{ha}^{-1} \mathrm{yr}^{-1}$ in 2000 , or by about $40 \%$ between 1995 and 2010 (Smolders and Six 2013). 
Fig. 8 a Change in copper $(\mathrm{Cu})$ concentration in topsoil $(0-0.20 \mathrm{~m})$ over time at Igelösa. b Change in mercury $(\mathrm{Hg})$ concentration in topsoil $(0-0.20 \mathrm{~m})$ over time at Igelösa

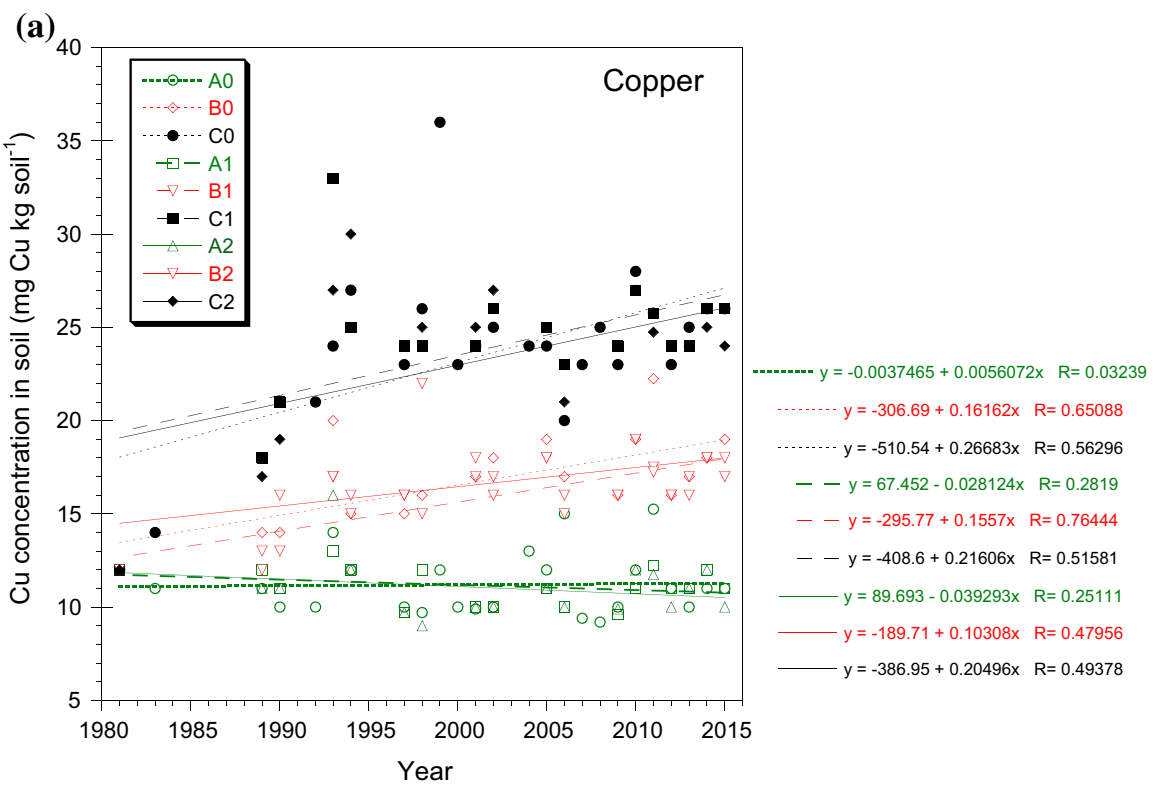

(b)

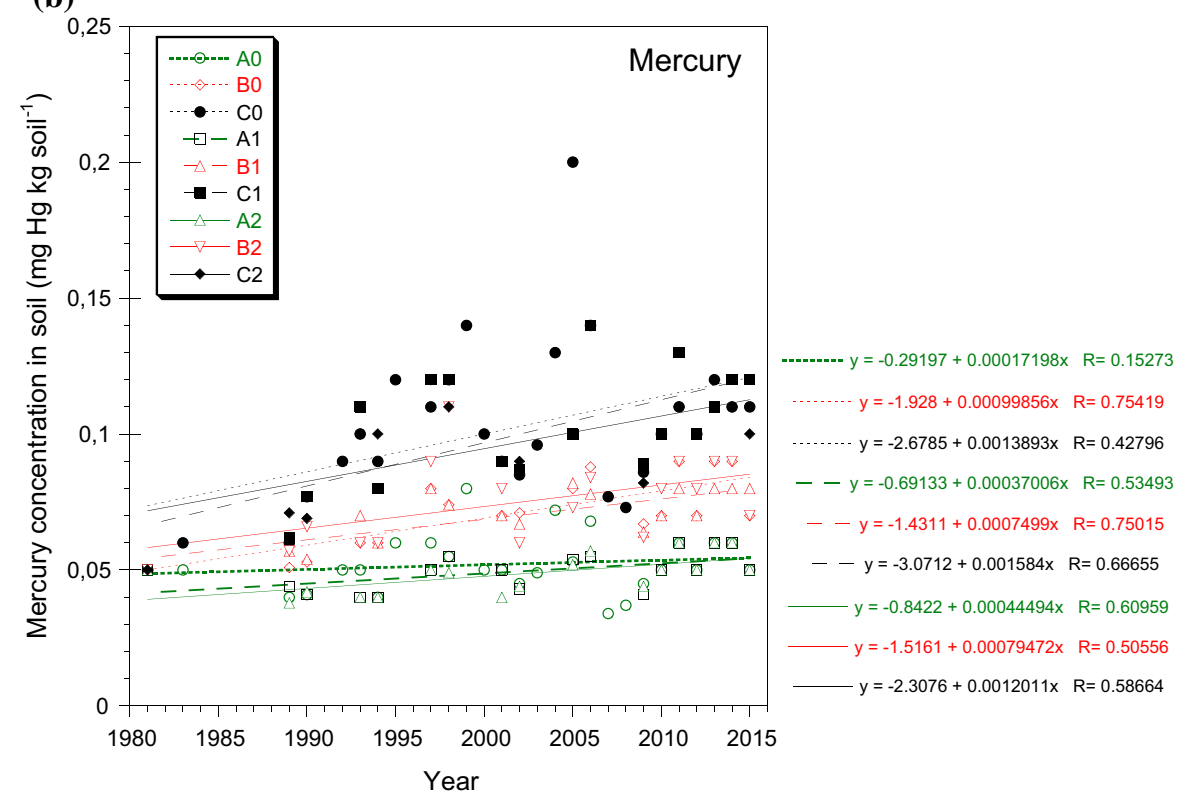

Metals in plants

Nutrient availability for plants depends on the type of organic substrate, climate and soil properties. Stabilised organic matter, such as aged SS, has a high affinity for binding heavy metals, among other elements (Smith 2009b). López-Rayo et al. (2016) found that of the elements they studied, only $\mathrm{Zn}$ and $\mathrm{Cu}$ concentrations were significantly elevated in soil treated with urban waste. In oat grain, $\mathrm{Cd}$ was significantly elevated in an SS treatment supplying the legally permissible level according to EU legislation for over 200 years, but even in this extreme case the concentration of $\mathrm{Cd}$ in grain did not exceed the relevant EU limit for $\mathrm{Cd}$ content. Zinc and $\mathrm{Cu}$ are essential elements for both plants and animals, which means that deficiency is harmful, and they may even modulate toxic effects by other elements (Whitfield et al. 2010). 
Hamnér and Kirchmann (2015) studied the effects of long-term use of manure and SS on the trace element composition of cereal grain samples from ongoing field experiments in Sweden and found that application of organic residues resulted in higher grain concentrations of $\mathrm{Zn}$ at several locations, but not all locations. They concluded that added trace metals present in organic fertilisers are not easily available to crops and that changes in soil properties, such as $\mathrm{pH}$, and root proliferation often are of greater importance for crop uptake. They also concluded that application of SS with a low Cd content to agricultural soil does not pose a high risk of increased $\mathrm{Cd}$ concentrations in crops.

\section{Other contaminants}

Concerns have been raised concerning organic contaminants in SS (e.g. Smith 2009a). Although much of the SS in Europe is subject to control, it may still contain unwanted compounds (Bloem et al. 2017). Certification systems such as Revaq in Sweden (Mattsson et al. 2017), aimed at systematic control of sources, have helped to ensure that the quality of SS has considerably improved over time (Kirchmann et al. 2017). Field studies at Petersborg have also shown that soil microorganisms can rapidly degrade organic compounds, as shown by the following two examples:

Österås et al. (2015) analysed soil samples from Igelösa and Petersborg and samples of the SS applied in 2014. Their investigation showed that the concentrations of perfluorooctane sulfonate (PFOS), perfluoroalkyls (PFOAs), brominated flame retardants (PBDEs), galaxolide, tonalide and di-(2-ethylhexyl)phthalate (DEHP) were enriched in soils amended with SS in the previous autumn, compared with in unamended control soils. However, none of these organic compounds was detected in grain of winter wheat grown in the experimental fields in Petersborg in the study year. For most substances, expected levels in crops were so low that they could not be detected within the analytical reporting limits. Thus those authors concluded that the levels of organic contaminants in soil after long-term SS addition do not pose a risk to the soil ecosystem or humans (Österås et al. 2015).

In a field study at Petersborg in 2015, Magnér et al. (2016) analysed the fate of 24 different organic compounds used as pharmaceuticals. In samples of SS-amended soils, they found traces of four out of 24 pharmaceuticals investigated, at concentrations between 0.4 and $4.9 \mathrm{ng} \mathrm{g}^{-1} \mathrm{DM}$. They concluded that the pharmaceuticals analysed were retained and eventually degraded at the surface of the soil. This result is line with other findings showing that soil microorganisms degrade water-soluble organic compounds relatively quickly (e.g. Neumann et al. 2014). Moreover, SS is not harmful for microorganisms, since in a previous study we did not find any effect of SS on arbuscular mycorrhiza (Börjesson et al. 2014), which are otherwise believed to be sensitive to high phosphate additions.

\section{Conclusions}

- At one of two sites studied, SS application tended to increase crop yield over time but, when plant nutrients were not limiting, the effect was only significant for spring barley.

- Addition of SS and N fertiliser increased SOC directly through $\mathrm{C}$ input and indirectly through stimulation of primary production. Treatment effects on SOC were highest in the top $0.20 \mathrm{~m}$ soil layer, but almost as high in the $0.20-0.40 \mathrm{~m}$ layer at Petersborg, where the subsoil was sampled. SOC changes below the topsoil should thus be considered in soil $\mathrm{C}$ balance studies.

- The nutrient value of the SS applied was limited, but it lowered soil bulk density. This improvement in soil physical properties may be more important for production than the nutrient content of SS.

- Normal doses of SS do not increase soil concentrations of heavy metals, except for copper, mercury and zinc, and do not result in elevated concentrations of heavy metals in grain.

Acknowledgements Thanks to Per-Göran Andersson and the Rural Economy and Agricultural Societies (Hushållningssällskapet i Skåne) for maintaining the experiments and for providing us with access to data. The experiments are funded by the regional water and wastewater utility VA SYD (the municipalities Burlöv, Eslöv, Lund and Malmö), the municipalities Kävlinge, Lomma, Staffanstorp, Svedala and Trelleborg, Sysav-the South Scania Waste Company, and the Swedish Water and Wastewater Association. 
Open Access This article is distributed under the terms of the Creative Commons Attribution 4.0 International License (http:// creativecommons.org/licenses/by/4.0/), which permits unrestricted use, distribution, and reproduction in any medium, provided you give appropriate credit to the original author(s) and the source, provide a link to the Creative Commons license, and indicate if changes were made.

\section{References}

Andersson P-G (2015) Slamspridning på åkermark—fältförsök med kommunalt avloppsslam från Malmö och Lund under åren 1981-2014 (Sludge spreading on agricultural landfield tests with municipal sewage sludge from Malmö and Lund in the years 1981-2014). Hushållningssällskapens rapportserie 17 . http://hushallningssallskapet.se/wpcontent/uploads/2015/05/slamrapport-2015.pdf

Andriamananjara A, Rabeharisoa L, Prud'homme L, Morel C (2016) Drivers of plant-availability of phosphorus from thermally conditioned sewage sludge as assessed by isotopic labeling. Front Nutr 3:19. https://doi.org/10.3389/ fnut. 2016.00019

Antoniadis V, Koutroubas SD, Fotiadis S (2015) Nitrogen, phosphorus, and potassium availability in manure- and sewage sludge-applied soil. Commun Soil Sci Plant Anal 46:393-404. https://doi.org/10.1080/00103624.2014. 983241

Bergkvist P, Jarvis N, Berggren D, Carlgren K (2003) Longterm effects of sewage sludge applications on soil properties, cadmium availability and distribution in arable soil. Agric Ecosyst Environ 97:167-179. https://doi.org/10. 1016/S0167-8809(03)00121-X

Bloem E, Albihn A, Elving J, Hermann L, Lehmann L, Sarvi M, Schaaf T, Schick J, Turtola E, Ylivainio K (2017) Contamination of organic nutrient sources with potentially toxic elements, antibiotics and pathogen microorganisms in relation to $\mathrm{P}$ fertilizer potential and treatment options for the production of sustainable fertilizers: a review. Sci Total Environ 607:225-242. https://doi.org/10.1016/j.scitotenv. 2017.06.274

Bolinder MA, Janzen HH, Gregorich EG, Angers DA, VandenBygaart AJ (2007) An approach for estimating net primary productivity and annual carbon inputs to soil for common agricultural crops in Canada. Agric Ecosyst Environ 118:29-42. https://doi.org/10.1016/j.agee.2006. 05.013

Bolinder MA, Kätterer T, Poeplau C, Börjesson G, Parent LE (2015) Net primary productivity and below-ground crop residue inputs for root crops: potato (Solanum tuberosum L.) and sugar beet (Beta vulgaris L.). Can J Soil Sci 95:87-93. https://doi.org/10.4141/CJSS-2014-091

Börjesson G, Kirchmann H, Kätterer T (2014) Four Swedish long-term field experiments with sewage sludge reveal a limited effect on soil microbes and on metal uptake by crops. J Soils Sediments 14:164-177. https://doi.org/10. 1007/s11368-013-0800-5

Calleja-Cervantes ME, Aparicio-Tejo PM, Villadas PJ, Irigoyen I, Irañeta J, Fernández-González AJ, Fernández-López M,
Menéndez S (2017) Rational application of treated sewage sludge with urea increases GHG mitigation opportunities in mediterranean soils. Agric Ecosyst Environ 238:114-127. https://doi.org/10.1016/j.agee.2016.09.021

Egnér H, Riehm H, Domingo WR (1960) Untersuchungen über die chemische Bodenanalyse als Grundlage für die Beurteilung des Nährstoffzustandes der Böden. II. Chemische Extraktionsmethoden zur Phosphor- und Kaliumbestimmung. Kungliga Lantbrukshögskolans Annaler 26:199-215 (in German)

Ellert BH, Bettany JR (1995) Calculation of organic matter and nutrients stored in soils under contrasting management regimes. Can J Soil Sci 75:529-538. https://doi.org/10. 4141/cjss95-075

European Commission (2016) Proposal for a regulation on the making available on the market of CE marked fertilising products and amending regulations (EC) no 1069/2009 and (EC) no 1107/2009. http://ec.europa.eu/DocsRoom/ documents/15949. Accessed 18 Jan 2017

European Commission (2017) Sewage sludge. http://ec.europa. eu/environment/waste/sludge/index.htm. Accessed 10 Nov 2017

Eurostat (2015) Water statistics. Eurostat Statistics Explained. http://ec.europa.eu/eurostat/statistics-explained/index. php/Water_statistics. Accessed 18 Jan 2017

Gan YT, Campbell CA, Janzen HH, Lemke RL, Basnyat P, McDonald CL (2009) Carbon input to soil from oilseed and pulse crops on the Canadian prairies. Agric Ecosyst Environ 132:290-297. https://doi.org/10.1016/j.agee.2009.04. 014

Gibbs PA, Chambers BJ, Chaudri AM, McGrath SP, CarltonSmith CH, Bacon JR, Campbell CD, Aitken MN (2006) Initial results from a long-term, multi-site field study of the effects on soil fertility and microbial activity of sludge cakes containing heavy metals. Soil Use Manage 22:11-21. https://doi.org/10.1111/j.1475-2743.2006.00003.x

Hamnér K, Kirchmann H (2015) Trace element concentrations in cereal grain of long-term field trials with organic fertilizer in Sweden. Nutr Cycl Agroecosyst 103:347-358. https://doi.org/10.1007/s10705-015-9749-7

Heimersson S, Svanström M, Cederberg C, Peters G (2017) Improved life cycle modelling of benefits from sewage sludge anaerobic digestion and land application. Resour Conserv Recycl 122:126-134. https://doi.org/10.1016/j. resconrec.2017.01.016

Hénin S, Dupuis M (1945) Essai de bilan de la matière organique du sol. Ann Agron 15:17-29

Inglezakis VJ, Zorpas AA, Karagiannidis A, Samaras P, Voukalli I, Sklari S (2014) European Union legislation on sewage sludge management. Fresenius Environ Bull 23(2a):635-639

Kätterer T, Andrén O, Jansson P-E (2006) Pedotransfer functions for estimating plant available water and bulk density in Swedish agricultural soils. Acta Agric Scand Sec B 56:263-276. https://doi.org/10.1080/09064710500310170

Kätterer T, Bolinder MA, Andrén O, Kirchmann H, Menichetti L (2011) Roots contribute more to refractory soil organic matter than above-ground crop residues, as revealed by a long-term field experiment. Agric Ecosyst Environ 141:184-192 
Kätterer T, Börjesson G, Kirchmann, H (2014) Changes in organic carbon in topsoil and subsoil and microbial community composition caused by repeated additions of organic amendments and $\mathrm{N}$ fertilisation in a long-term field experiment in Sweden. Agric Ecosys Environ 189:110-118. https://doi.org/10.1016/j.agee.2014.03.025

Kirchmann H, Börjesson G, Kätterer T, Cohen Y (2017) From agricultural use of sewage sludge to nutrient extraction: a soil science outlook. Ambio 46:143-154. https://doi.org/ 10.1007/s13280-016-0816-3

López-Rayo S, Laursen KH, Lekfeldt JDS, Grazie FD, Magid J (2016) Long-term amendment of urban and animal wastes equivalent to more than 100 years of application had minimal effect on plant uptake of potentially toxic elements. Agric Ecosyst Environ 231:44-53. https://doi.org/ 10.1016/j.agee.2016.06.019

Mackay JE, Cavagnaro TR, Jakobsen I, Macdonald LM, Grønlund M, Thomsen TP, Müller-Stöver DS (2017) Evaluation of phosphorus in thermally converted sewage sludge: $\mathrm{P}$ pools and availability to wheat. Plant Soil 418:307-317. https://doi.org/10.1007/s11104-017-3298-6

Magnér J, Rosenqvist L, Rahmberg M, Graae L, Eliaeson K, Örtlund L, Fång J, Brorström-Lundén E (2016) Fate of pharmaceutical residues-in sewage treatment and on farmland fertilized with sludge. IVL report no. B 2264, IVL Swedish Environmental Research Institute Ltd, Stockholm, Sweden. http://www.ivl.se/download/18.29aef808 155c0d7f05054e/1473086619449/B2264.pdf. Accessed 31 Oct 2016

Mattsson A, Finnson A, l'Ons D (2017) Heavy metal content of Swedish municipal wastewater sludge-status and goals. Water Sci Technol 76:869-876. https://doi.org/10.2166/ wst.2017.277

Mininni G, Blanch AR, Lucena F, Berselli S (2015) EU policy on sewage sludge utilization and perspectives on new approaches of sludge management. Environ Sci Pollut Res 22:7361. https://doi.org/10.1007/s11356-014-3132-0

Nawara S, Van Dael T, Merckx R, Amery F, Elsen A, Odeurs W, Vandendriessche H, Mcgrath S, Roisin C, Jouany C, Pellerin S, Denoroy P, Eichler-Löbermann B, Börjesson G, Goos P, Akkermans W, Smolders E (2017) A comparison of soil tests for available phosphorus in long-term field experiments in Europe. Eur J Soil Sci 68:873-885. https:// doi.org/10.1111/ejss.12486

Neumann D, Heuer A, Hemkemeyer M, Martens R, Tebbe CC (2014) Importance of soil organic matter for the diversity of microorganisms involved in the degradation of organic pollutants. ISME J 8:1289-1300. https://doi.org/10.1038/ ismej.2013.233

Nizzetto L, Futter M, Langaas S (2016) Are agricultural soils dumps for microplastics of urban origin? Environ Sci Technol 50:10777-10779. https://doi.org/10.1021/acs.est. $6 \mathrm{~b} 04140$

Österås AH, Allmyr M, Sternbeck J (2015) Screening of organic pollutants in sewage sludge amended arable soils. Report WSP 2015-11-24, for Swedish Environmental Production Agency. http://www.svensktvatten.se/globalassets/avloppoch-miljo/uppstromsarbete-och-kretslopp/revaq-certifiering/ naturvardsverket-rapport-screening-of-organic-pollutants-insewage-sludge-amended-arable-soils_151124-2.pdf
Pacyna JM, Pacyna EG, Aas W (2009) Changes of emissions and atmospheric deposition of mercury, lead, and cadmium. Atmos Environ 43:117-127. https://doi.org/10. 1016/j.atmosenv.2008.09.066

Persson T, Svensson M, Finnson A (2015) REVAQ certified wastewater treatment plants in Sweden for improved quality of recycled digestate nutrients. In: Biogas in society. A case story from IEA bioenergy task 37 "energy from biogas". http://www.ieabioenergy.com/publications/revaqcertified-wastewater-treatment-plants-in-sweden-for-impro ved-quality-of-recycled-digestate-nutrients/. Accessed 03 May 2018

Pitombo LM, Carmo JB, de Maria IC, de Andrade CA (2015) Carbon sequestration and greenhouse gases emissions in soil under sewage sludge residual effects. Sci Agric 72:147-155. https://doi.org/10.1590/0103-9016-2013-03 52

Poeplau C, Kätterer T, Bolinder MA, Börjesson G, Berti A, Lugato E (2015) Low stabilization of aboveground crop residue carbon in sandy soils of Swedish long-term experiments. Geoderma 237-238:246-255. https://doi.org/ 10.1016/j.geoderma.2014.09.010

Poeplau C, Vos C, Don A (2017) Soil organic carbon stocks are systematically overestimated by misuse of the parameters bulk density and rock fragment content. Soil 3:61-66. https://doi.org/10.5194/soil-3-61-2017

Rigby H, Clarke BO, Pritchard DL, Meehan B, Beshah F, Smith SR, Porter NA (2016) A critical review of nitrogen mineralization in biosolids-amended soil, the associated fertilizer value for crop production and potential for emissions to the environment. Sci Total Environ 541:1310-1338. https://doi.org/10.1016/j.scitotenv.2015.08.089

Smith SR (2009a) Organic contaminants in sewage sludge (biosolids) and their significance for agricultural recycling. Philos Trans R Soc A 367:4005-4041. https://doi.org/10. 1098/rsta.2009.0154

Smith SR (2009b) A critical review of the bioavailability and impacts of heavy metals in municipal solid waste composts compared to sewage sludge. Environ Int 35:142-156. https://doi.org/10.1016/j.envint.2008.06.009

Smith P, Powlson DS, Glendining MJ, Smith JU (1997) Potential for carbon sequestration in European soils: preliminary estimates for five scenarios using results from long-term experiment. Glob Change Biol 3:67-79. https:// doi.org/10.1046/j.1365-2486.1997.00055.x

Smolders E, Six L (2013) Revisiting and updating the effect of phosphorus fertilisers to cadmium accumulation in European agricultural soils. Report, European Commission: Scientific Committee on Health and Environmental Risks (SCHEER), 58 pp. http://ec.europa.eu/health/scientific committees/environmental_risks/docs/scher_o_168_rd_en. pdf. Accessed 23 Oct 2017

SNFS (1994) Kungörelse med föreskrifter om skydd för miljön, särskilt marken, när avloppsslam används i jordbruket (Proclamation of regulations on the protection of the environment, especially the soil, when sewage sludge is used in agriculture). Statens naturvårdsverks författningssamling 1994:2. http://www.naturvardsverket.se/ Stod-i-miljoarbetet/Rattsinformation/Foreskrifter-allmanna$\mathrm{rad} / \mathrm{NFS} / 1994 / \mathrm{SNFS}$-19942 - Skydd-for-miljon-nar-avlopps slam-anvands-i-jordbruket/. Accessed 18 Jan 2017 
STEM (2016) Produktion och användning av biogas och rötrester år 2015. ES 2016:04. https://www.energimyn digheten.se/globalassets/nyheter/2016/es-2016-04-produk tion-och-anvandning-av-biogas-och-rotrester-ar-2015.pdf

Swedish Board of Agriculture (2016) Rekommendationer för gödsling och kalkning 2017 (Recommendations for fertilisation and lime 2017). Jordbruksinformation 24. http:// webbutiken.jordbruksverket.se/sv/artiklar/jo1624.html. Accessed 25 Oct 2017 (in Swedish)

SWWA (The Swedish Water \& Wastewater Association) (2016) Revaq årsrapport 2015. http://www.svensktvatten.se/ globalassets/avlopp-och-miljo/uppstromsarbete-ochkretslopp/revaq-certifiering/revaq-arsrapport-2015.pdf. Accessed 16 Jan 2017

Tian G, Granato TC, Cox AE, Pietz RI, Carlson CR, Abedin Z (2009) Soil carbon sequestration resulting from long-term application of biosolids for land reclamation. J Environ Qual 38:61-74. https://doi.org/10.2134/jeq2007.0471

Vogel C, Sekine R, Steckenmesser D, Lombi E, Steffens D, Adam C (2017) Phosphorus availability of sewage sludge- based fertilizers determined by the diffusive gradients in thin films (DGT) technique. J Plant Nutr Soil Sci 180:594-601. https://doi.org/10.1002/jpln.201600531

Whitfield JB, Dy V, McQuilty R, Zhu G, Heath AC, Montgomery GW, Martin NG (2010) Genetic effects on toxic and essential elements in humans: arsenic, cadmium, copper, lead, mercury, selenium, and zinc in erythrocytes. Environ Health Perspect 118:776-782. https://doi.org/10. 1289/ehp.0901541

Wiklert P, Andersson S, Weidow B, Karlsson I, Håkansson A (1983) Studier av markprofiler i svenska åkerjordar. Del X. Malmöhus och Kristianstads län. Swedish University of Agricultural Sciences, Department of Soil Sciences, Division of Agricultural Hydrotechnics, Report 136 (in Swedish)

Xu H, Zhang H, Shao L, He P (2012) Fraction distributions of phosphorus in sewage sludge and sludge ash. Waste Biomass Valorization 3:355-361. https://doi.org/10.1007/ s12649-011-9103-5 